WOODFORD D. MCCLELLAN

\title{
SERBIA AND SOCIAL DEMOCRACY,
}

I $870-187^{1}$

Socialist thinking and political activity took root in the Balkans in the period between the revolutions of $1848-49$ and the Congress of Berlin, and for nearly a century historians have interpreted the phenomenon as an extension of contemporary developments in Russia. This position, entrenched in Russian historiography prior to 1917, became the official view of Soviet historians. Neither in the inter-war period nor since I945 have any alternative interpretations been produced by Balkan scholars. ${ }^{2}$

There is naturally a considerable body of evidence which, when taken by itself, supports the traditional view of the origins of the revolutionary movement in the Balkans. The Russian careers of many Balkan revolutionaries are reasonably well documented; the influence of the Russian Left upon Balkan radical thought was, as we have long known, significant. But this is far from the complete story, as this article, through an examination of the Serbian experience in the crucial decade of the 1870 's, will attempt to demonstrate. Certain

1 The author wishes to express his thanks to the American Council of Learned Societies for its support of the research for this study.

2 Western scholars have, with a handful of exceptions, ignored the social history of the Balkans. One of the exceptions is C. E. Black's "Russia and the Modernization of the Balkans", in: C. Jelavich, ed., The Balkans in Transition, Berkeley and Los Angeles, $1_{96}$, pp. I45-183. This is a fine study which runs counter to the generally accepted view of things, and as such provides a valuable corrective. Among the works which tend to exaggerate the significance of Russian influence, $\mathrm{I}$ am uneasy about the first chapter of my own Svetozar Marković and the Origins of Balkan Socialism, Princeton, 1964. The latest Yugoslav research does not indicate that many new directions are being pursued in that country; see Dragutin Lekovic, "Zur Verbreitung der Ideen der I. Internationale in den jugoslawischen Ländern", in: Beiträge zur Geschichte der deutschen Arbeiterbewegung (Berlin), VI, I964, Sonderheft "Marx, Engels und die I. Internationale. Protokoll der wissenschaftlichen Konferenz zum Ioo. Jahrestag der Gründung der I. Internationale", pp. 171-1 73. Lekovićs brief presentation shows the Yugoslavs still too enraptured with the work of Svetozar Marković to pursue the question of the origins of Marxist influence in the South Slav lands. A much better work which deals, however, largely with Svetozar Markovic's influence upon Serbian literature, is Vitomir R. Vuletić's Svetozar Marković i ruski revolucionarni demokrati (Novi Sad, 1964). 
evidence long neglected has recently come to light, bringing with it implications and suggestions not without interest to those concerned with the history of European socialism.

Tsar Alexander II's consul in Belgrade was among the first to sound the tocsin concerning the advent of the socialist movement in the South Slav lands. In July of 187 I N. P. Shishkin reported to his superiors that the young Serbs who had recently founded the newspaper Radenik (The Worker) boldly acknowledged the fact that many of their number belonged to the International Workingmen's Association. The Russian consul wrote that the Serbian Internationalists were also (as it was rumored of all in the organization) ardent supporters of the Paris Commune, which "order of things" they sought to introduce into Serbia. ${ }^{1}$

Seeking to explain the appearance of radical socialists in backward Serbia, Shishkin in a subsequent dispatch blamed "people educated in Russia" for corrupting the Serbian youth. The Metropolitan of Belgrade, he wrote, had told him of the existence, in Russian institutions of higher education, of secret societies having close ties with the International. The cleric and the Russian diplomat agreed that the Serbs who had studied in Russia, and especially those who had been at the Kiev seminary, had returned to Serbia "thoroughgoing nihilists". 2

But Shishkin and the Metropolitan were in error. For instance, of the nine individuals on the staff of Radenik at its founding, only one, Svetozar Marković, had studied in Russia. Marković was the leader of the group and the most important South Slav socialist of the igth century, and it is indeed clear that much of his thought and work reflected the influence of the Russian "revolutionary democrats", especially Chernyshevsky; but his intimate contacts with the Russian revolutionaries have been allowed by most writers to obscure his equally significant relations with social democrats in Central Europe. ${ }^{3}$ Thus it is not to Russia, or at least not solely to Russia, that we must look for the origins of the socialist movement in Serbia. Let us turn our attention to Switzerland, where Svetozar Marković went in

1E. N. Kusheva, "Iz russko-serbskikh revoliutsionnykh sviazei $1870-k h$ godov", in: Uchënye zapiski Instituta Slavianovedeniia, I, r949, P. 35 I.

2 V. N. Kondrat'eva, "Novye arkhivnye materialy po istorii Ob'edinënnoi serbskoi omladiny", ibid., XX, 1960, pp. 308-309.

3 Among the other socialists the only two who studied at the Kiev seminary were Živojin Zujović and Vasa Pelagić; Žujović died in 1870 , and was only vaguely a socialist, and the archimandrite Pelagić was under Turkish house arrest in Asia Minor from 1869 until 1871 . 
March of 1869 after spending almost three years as a student in St. Petersburg.

As a consequence of a series of meetings in April and May of 1869 , four Serbian student engineers in Zürich formed a group which one of their number, Marković, christened the "radical party". United in the beginning chiefly by their common disaffection with the Serbian liberal party, these young "radicals" - Nikola Pašić, Pera Velimirović, Djura Ljočić and Marković - and the many who soon joined them sought in the ensuing decade an ideological program which would accurately reflect their evaluation of Serbian history and contemporary conditions and their hopes for Serbia's future. The liberal nationalism, or national liberalism, which their Serbian teachers had attempted to instill in them in the I 860's had little appeal by the end of the decade. The old generation had been captivated by Cobden, Mazzini and the young Gladstone; the young radicals went on to Büchner, Darwin and Marx. ${ }^{1}$

Whether out of youthful idealism or a rational evaluation of the political situation in their homelands, politically literate students from backward countries not infrequently become attached to radical ideologies encountered abroad. It is therefore scarcely surprising that the young Serbs who were studying in Central and Western Europe in the late I $860^{\circ}$ 's and early I 870's became interested in the activities and teachings of the First International. Svetozar Marković was instrumental in establishing contact between the Serbian students in Zürich and the Social Democrats in the Suisse romande. He was in touch with the Russian section of the International, ${ }^{2}$ which was located in Geneva, as early as March of 1870 and later wrote an article on Serbian politics which that section's journal published in May of the same year. ${ }^{3}$

In the summer of 1870 Marković and Djura Ljočić returned to Serbia, while Velimirović and Pašić remained in Switzerland to continue their studies. In November of 1870 Velimirović wrote an interesting letter to Johann Philipp Becker, ${ }^{4}$ who had sponsored the Russian section for admission to the International, and whose

${ }^{1}$ See Vasa Cubrilović, Istorija političke misli u Srbiji XIX veka, Belgrade, 1958, chs. V-VII.

2 On the Russian section see B.P. Koz'min, Russkaia sektsiia pervogo Internatsionala, M. 1957; B. S. Itenberg, Pervyi Internatsional i revoliutsionnaia Rossiia, M. 1964; and my bibliographical article "The Russian Section of the First International", in: Cahiers de l'Institut de Science Économique Appliquée, August 1964, pp. I 77-198.

3 "The Political and Economic Situation of the Working Class in Serbia", in: Narodnoe Delo (The People's Cause), nos. 2 and 3, May 1870.

4 Internationaal Instituut voor Sociale Geschiedenis (Amsterdam), Becker Papers, D III 147 . 
name the Serbs had apparently gotten from Utin and other Russians. Velimirović wrote that he had long intended to "begin the study of the historical development of our great International Workers' Association", but that he did not have the proper sources. Unable to obtain the transcripts of the proceedings of the congresses of the International, Velimirovic asked Becker to send them or tell him where they could be obtained. The letter concluded "Mit socialdemokratischen Gruss" - this was to be sure a matter of form in the socialist movement, but it is interesting here because it is the first time, so far as can be known, that any Serb used it.

In the absence of documentary evidence (other than his article in Narodnoe delo) concerning Svetozar Marković's relations with the Russian section of the International, Velimirovićs letter to Becker stands as the first recorded attempt of the young Serbian radicals to establish contact with the social democrats of Central Europe. We know beyond any question that Marković was indeed in communication with the Russians in Geneva, and it is to be assumed that Velimirović was acting on Marković's instructions or at least at his suggestion when he wrote to Becker.

We can be reasonably certain that Becker replied to Velimirović and supplied some of the materials he requested. Becker preserved Velimirovićs letter (as he did most of his correspondence) and classified it among his papers dealing with the International. Some of the news of the International carried in Radenik came from Geneva, and it was either Becker or Nikolai Utin and the Russian section who supplied it. It is in any event unlikely that Becker would have passed up the opportunity to win new converts; and subsequent developments were to show the extent of his contact with the Serbs.

One of the first to join the original group of Serbian radicals in Zürich was Mita Rakić, who studied in Munich and Göttingen and took occasional courses at the Polytechnikum in Zürich. Late in December of 1870 Rakić was in London, possibly in connection with his translation of John William Draper's History of the Intellectual Development of Europe. ${ }^{1}$ Whatever the reasons for his appearance in London, there was an interesting by-product of the visit. On 20 December 1870 Rakic wrote the following letter, the first on record that Karl Marx received from a South Slav :2

\footnotetext{
1 The first volume of the Rakić translation was published in Belgrade in 1871 . He also translated Les Misérables and some of Heine's works.

2 IISG, Marx-Engels Correspondence, D 3716.
} 
Mein Herr,

Ein grosser Verehrer, und, wenn ich mir schmeicheln darf, ein Schüler von Ihnen, aus Serbien, - ich wäre glücklich Sie zu sehen und sprechen zu können.

Wenn Sie nichts dagegen haben, so bitte lassen Sie mir gefälligst zu wissen wann sind Sie zu sprechen.

Ich zeichne mich mit aller Hochachtung,

$\mathrm{Ihr}$

gehorsamster Diener

\section{Mita Rakitch}

We do not know exactly what Marx wrote in reply. That his answer was prompt and cordial is obvious from Rakić's second letter written on 22 December. ${ }^{1}$ He told Marx that "a big mistake" had prevented him from keeping their appointment: he had misread Marx's letter and instead of going to No. I Maitland Park went to No. 4, where he was "very rudely sent away". Rakić apologized profusely for his error and offered, if Marx would still consent to see him, to come around after the holidays.

It appears that the two men eventually got together. There is no record of their meeting, but early in February of 1871 Svetomir Nikolajević, the noted Serbian politician and writer who was then studying in London, sent a curious message to Marx. ${ }^{2}$ Noting that his friend Rakić had departed for France and had no plans to go back to Britain, Nikolajevic told Marx that he was returning "the Engels book" in Rakić's name. From this we can deduce the following not very significant course of events: Rakić met Marx at the latter's home in January of $187 \mathrm{I}$, borrowed a book written by or belonging to Engels, and upon his departure for France left the book with his countryman in London, Nikolajević.

This was the end of Rakić's rôle as "admirer and pupil" of Marx,

${ }^{1}$ Ibid, D 3717 .

2 Ibid., D 3538 . Since this letter is in the old German orthography, and has a signature in the modern script which would appear to be "L. Nikolajevitch", the problem of identifying its author (whose handwriting is all but illegible) has been rather difficult. It is however known that Svetomir Nikolajevic was in London at the time, that he and Rakic came from neighboring villages in Serbia, that he was a friend of Pašić and Pera Todorović, and that he was later one of the founders of the Serbian Radical party. The handwriting (in Serbian, and in the Cyrillic script) of an I 886 letter written by Svetomir Nikolajević bears a certain resemblance to the $187 \mathrm{I}$ letter in German, and the signatures are very similar (the 1886 letter was kindly loaned to me through my friend Dr. Dimitrije Prodanović by the Državni Arhiv Narodne Republike Srbije). 
and perhaps Marx, with his decided lack of enthusiasm for the Slavs, deserved the unsatisfactory and eccentric Rakic as his first South Slav visitor. A talented but erratic personage, Rakic entered the service of the Serbian government in the same year (187I) and three years later was appointed to a high post in the Interior Ministry of Aćim Čumić, who was later to be blamed by many socialists for the death of Svetozar Markovic. ${ }^{1}$

Where Rakić merely probed and withdrew others pressed on. In January of I 87 I Becker's Der Vorbote, the official organ of the German sections of the International in Switzerland, listed among the recent contributors of funds to assist publication "Liotitsch, Semendra (Serbien) 3 Frk. 75 Cent". ${ }^{2}$ Vlada M. Ljotić, an ardent supporter and friend of the Serbian Karadjordjević dynasty, ${ }^{3}$ met Becker in Geneva in the autumn of 1870 and the two men soon became friends. ${ }^{4} \mathrm{It}$ is unclear whether Ljotić mailed his contribution to Der Vorbote from Smederevo (Semendra) or whether the journal merely listed his home town; the political climate in Serbia, despite the "truce" of 1869 , remained unhealthy for Karadjordjevists, and it seems improbable that one so closely identified with the rival dynasty as Ljotic would have gone home at that time. In any event, wherever he spent the winter of $1870-71$, Ljotic was back in Geneva in the spring of $187 \mathrm{I}$. His name appeared as one of the eighteen signatories (headed by Becker) to Der Vorbote's "Brudergruss an die Bundesgenossen der Commune zu Paris" in April of $1871 .^{5}$ As we shall see shortly, Ljotić did not limit his contacts with the International to the donation of a few francs and his signature.

The tragic events of the Paris Commune had a profound effect upon radical social movements throughout Europe. Serbia, still in the throes of the transformation from Asia to Europe, was no exception. As the Russian consul had told his government, the support of the young Serbian radicals for the Commune was unequivocal. Svetozar Marković wrote a series of brilliant, passionate articles in Radenik in defense of the Commune. ${ }^{6}$ Some of the Serbian literati won the eternal hatred of the conservative elements for their eulogies of the Communards, and in the Hungarian-ruled Vojvodina the

1 For a little more on Rakić see Vuletić, Svetozar Marković, p. 204.

2 Der Vorbote, no. I, January i 871 , p. 16.

3 See below pp. 16 and 20.

4 Archives d'Etat de Genève (AEG), Étrangers Dh 24, p. 53, no. 53033 . This source gives only the dates of Ljotic's visit to Geneva, but subsequent developments were to indicate that he met Becker at this time.

${ }^{5}$ Der Vorbote, no. 4, April 1871 , pp. 53-55.

"The Fall of the Paris Commune", in: Radenik, no. I, I June 1871 ; "The White Terror", ibid., nos. I 7-21, 8-1 7 July I 871 . 
Serbian newspaper Zastava (The Banner) defended the ideals of the Paris uprising. ${ }^{1}$

In the year of the Paris Commune the Serbian radicals strengthened their ties with social democrats in Switzerland. In April Svetozar Marković contributed an unspecified sum to assist Der Vorbote, ${ }^{2}$ and in July L'Égalité, the journal of the Geneva Central section of the International, carried the following item:

"Servie. Le partie socialiste s'organise à Belgrade. Il vient de fonder un journal hebdomaire sous le titre de Radenik (le Travailleur). Encore une contrée où l'Internationale plante son drapeau. Jules Favre l'ira dire au Grand-Turc."3 Interestingly enough, Radenik published an attack on Jules Favre on the same day that L'Égalité carried the above item. The Serbian journal brought forth the old charges of Favre's improper conduct in the trial of Etienne Cabet and of his cuckolding of a French officer. These simultaneous references to Favre were probably coincidental, and in any case the matter is not of major significance, but it does lend weight to our assumption that the radicals in Belgrade were in direct contact with Geneva. These ties could have been made through the person of Vlada Ljotić, then in Geneva, or Nikolai Utin, the leader of the Russian section of the International who was also one of the editors of L'Égalité.

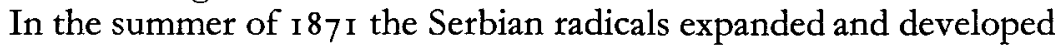
their contacts with the marxist wing of the International. Late in July the Leipzig Der Volksstaat, the most influential social-democratic newspaper and the official voice of the German marxists, published an item from the Vojvodina town of Pančevo. The author of the dispatch (either Jovan Pavlović or Nikola Marković) informed the German social democrats that "Among our national-liberal journals a social-democratic newspaper, Radenik... has finally made a place for itself." The "most important individual" on the editorial board, Svetozar Marković, "merits the recognition of Social Democracy, for he was the first to disseminate... [its] principles in our language." The work of Marković, and the high regard in which the International was held among the intelligentsia, were said to be evidence of the

\footnotetext{
1 For a good discussion of the problem see Kosta Milutinović, "Odjek Pariske komune u Srbiji i Vojvodini", in: Letopis Matice Srpske, vol. 367, I95 I, Pp. 420-437. See also my Marković, pp. 149-I 52.

2 Der Vorbote, no. 4, April I 871 , p. 64. On the subject of these contributions, it is interesting to note that Bakunin had earlier drawn the scorn of $S$. Borkheim for his own donation; see Der Vorbote, August I868, p. 128, and IISG, M-E Correspondence, D 513 , 5i4.

${ }^{3}$ L'Égalité, no. 2 2, 8 July 187 I.
} 
progress of social democratic principles in Serbia. The writer concluded with a summary of the prospects for socialism in Serbia, and noted that industry did not exist in the country; thus there were no class conflicts between bourgeoisie and proletariat. Lest the wrong conclusions be drawn, however, he insisted that "our workers must make a special effort to take the necessary social-democratic steps precisely because there are now no important property distinctions."1

The article in Der Volksstaat revealed much about the socialist movement in Serbia. It indicated the prestige already enjoyed by the young Svetozar Marković, and showed that his propagation of socialist theories had begun to take hold of the thinking of some among the Serbian intelligentsia. It further demonstrated that the Serbian radicals of the $1870^{\text {'s }}$ were confronted with the same dilemma which had plagued the Russian "men of the 'sixties": how to build socialism without a working class. N. G. Chernyshevsky and his followers, pondering the problem of Russia, had arrived at an essentially agrarian socialist answer; they understood the problem of the original accumulation of capital, but in their determination to find an alternative to capitalism they could but advance a rather vague plan for "agricultural-industrial communes".

The Serbs were facing the same problem a decade later, and the fact that Svetozar Marković eventually (in I 874) produced a program based largely on Chernyshevsky's theories has frequently been cited as proof of the Russian character of Serbian socialism in this period. This was simply not the case, either of Serbian socialism in general or of Marković. Leaving aside the fact that Chernyshevsky's thought was heavily influenced by Fourier and others, we should note first of all that there were many Serbian socialists who were intellectually oriented exclusively toward the West; the Russia of Pisarev and Chernyshevsky and Dobroliubov was popular among the Serbian intelligentsia, but that was not the real Russia, and no one in Serbia thought that it was. Secondly, Marković himself, having had the opportunity to spend nearly eighteen months in Switzerland, had the highest regard for the working class movement in Central and Western Europe, and he was greatly influenced by the thinking and the experience of that movement. Finally, we should note that the Russian Left of the r 860's was isolated, effectively sealed off from the main currents of the social movement in the West. At a time when the West was debating the merits of Marx, Proudhon, Lasalle and

\footnotetext{
1 Der Volksstaat, no. 61, 29 July 187r. Pavlović was the editor of the republican newspaper Pančevac (The Pančevan), and Nikola Marković, no relation to Svetozar, was one of his collaborators.
} 
others, the Russians were still marveling at Saint-Simon, Fourier and Louis Blanc. All this would change, of course, and change very rapidly, but in the late $1860^{\prime}$ 's and early $1870^{\prime}$ 's it was symbolic of the situation in Russia that the Russian section of the International was located in Geneva. The Serbs, on the other hand, were in direct and in a sense almost day to day contact with the working class movement in Central Europe. Thus the more modern socialist doctrines found an echo in Serbia before they were heard in Russia.

As his frequent references in Radenik clearly indicate, Svetozar Marković was receiving Der Volksstaat as early as June of 1871 . Later in the year Nikola Markovic subscribed to the newspaper, and there began to appear frequent cryptic, if not very portentous, messages in Der Volksstaat's "letterbox" concerning the South Slav friends of the journal: "S. in Belgrad: 2 fl. $30 \mathrm{kr}$. erhal. Das Bestellte ging ab." "M. in Pancova: $5 \mathrm{fl}$. österr. erh., Schriften folgen demnächst." Concerning this latter note, there was a wide variety of socialist literature available very cheaply through Der Volksstaat, and the "letterbox" indicates that many items went to Serbia and the Vojvodina."

Though there must have been some doubts about the contradictory nature of the Serbian socialist program as it was outlined in the dispatch from Pančevo, the German SDs responded affirmatively to the plea for recognition. In answer to an unknown communication, the Serbs sent the following note of thanks to Der Volksstaat:

"Ihre brüderliche Neigung gegen uns gibt uns neue Kräfte für die heilige Sache des menschlichen Geschlechts. Wir seben keinen Unterschied zwischen den Serben und den Deutschen. Mensch ist Mensch. Die Natur ernährt Einen wie die Andern. Warum sollte ein Serbe einen Deutschen hassen? Dieser Hass ist nur zu erklären aus Unbewusstsein des wahren Ziels des Menschengeschlechts. Aber wir sollen und wollen dieses Unbewusstsein durch Bildung ausrotten. Wir gehören zu der sozialdemokratischen Partei. Unser Organ "Radenik" ... welches seit Juni dreimal wöchentlich erscheint, hat jetzt über ein Tausend Abonnenten. Obgleich wir in Serbien nur Anfänger in diesem Prinzip sind, so hoffen wir dennoch, schöne Fortschritte zu machen."'2

The appearance of this letter, which was surely the work of Svetozar Marković, on the front page of the highly respected journal of the

${ }^{1}$ Der Volksstaat, nos. 78, 88 and 104 of 27 September, I November and 30 December I 871. For a list of some of the literature available see no. 47, 12 June 1872. Among the works listed is a German translation of a brochure written by A. A. Serno-Solov'evich, the first Russian émigré to establish firm ties with the International (and Marx).

2 Ibid., no. 87, 28 October 1871 . The item is dated Belgrade, 6/1 8 October. 
marxist wing of German social democracy marked the end of the first phase of the relations between Serbian radicals and Central European socialists. For the Serbs, the fact that the Germans and the Swiss now recognized them as a fraternal party was a triumph. And L'Égalité was correct in calling the establishment of the International in yet another corner of Europe a significant gain for the socialist movement. By the end of 1871 definite contacts had been established between the old parties at the center of things and the new group on the frontiers of Europe. But even this would have little meaning if the contacts were not carried forward, if action did not follow words.

In their attempt to develop a sound socialist program, and as part of their campaign against the nationalist liberal party in Serbia, the Serbian radicals moved toward a Yugoslav solution to the national question in the South Slav lands. Developments in Croatia seemed to favor the approach.

The radical movement in Croatia had an even more protracted, painful birth than its counterpart in Serbia. This despite the fact that the Croats, unlike the Serbs, had more genuine workers than intellectuals in their ranks. Attempts to form a union among Zagreb workers in 1869 were frustrated by the Hungarian authorities, but in I 872 a compositors' strike was successful in securing improved wages and working conditions. Out of the committee which had led the strike there emerged the leadership of the newly-formed Zagrebačko radničko društvo - Gewerbe Arbeiterverein, the name of which indicated the importance of the German (Austrian) workers in Croatia. ${ }^{1}$

Labor developments in Croatia received considerable attention in the social democratic press, especially in Der Volksstaat and the Vienna Der Volkswille. The Belgrade Radenik was silent, but with reason. The journal had risked suppression for its sympathetic treatment of the Croatian uprising at Rakovica under Eugen Kvaternik, ${ }^{2}$ and its reluctance to discuss subsequent events in Croatia at any length indicated prudence, and not indifference.

The published lists of Der Volksstaat's subscribers do not indicate any subscriptions in Croatia in I 872, but in Serbia Radenik subscribed for the calendar year. Nikola Marković continued to receive his copy in Pančevo, one Barjaktarević subscribed from Zemun, and a certain

${ }^{1}$ Josip Cazi, Počeci modernog radničkog pokreta u Hrvatskoj, I, Zagreb, n.d., pp. 6ff. Franjo Topolšćak was the society's first president. One writer has claimed that the Croatian intellectuals "lagged behind" the Serbs: A. G. Matoš, "Svetozar Markovic", in: Savremenik (Zagreb), I9I I, pp. 303-304.

2 Radenik, no. 76, I871. 
Nikolić in Pančevo was in contact with the journal. ${ }^{1}$ Nikola Marković was publicly thanked by Der Volksstaat in the spring of 1872 for his contribution to the cause of the "struggling tailors", 2 and his name appeared frequently in the journal's "letterbox."

The Radenik staff received Der Volkswille as well as its better known and more influential Leipzig counterpart. Svetozar Marković, however, denounced the "pseudo-marxists" of Der Volkswille who attacked as "utopian" the call for the abolition of standing armies and bureaucracies (a favorite Marković theme) and who sought to establish socialism within the existing Habsburg political framework. The Serbian socialist leader complained that "Our intelligentsia... has for the most part heard about the labor problem at ninth hand, and chiefly from German newspapers." 3 The subscription to L'Égalité which Marković ordered early in 1872 was an indication of his desire to put the German viewpoint into better perspective. ${ }^{4}$

Having skirted the fringes of suppression for months, Radenik was finally closed down by the Serbian government in May of 1872 . Svetozar Marković had moved to Novi Sad in the Vojvodina some weeks earlier, and he spent the ensuing year outside Serbia striving to reorganize the Serbian socialist movement.

In August of 1872 a Serbian "socialist" congress was organized and held in Zürich by the followers of Bakunin. Svetozar Marković attended; Bakunin was also present. There are few records of this meeting. It is known, however, that Bakunin won the majority of the Serbs in Zürich over to his side; that majority,composed of at most a score of individuals, "expelled" Markovic from the "Serbian socialist party". 5 This was utterly without meaning; in Serbia itself Marković continued to enjoy the support of the radically inclined intelligentsia. The Bakuninists never had much success in the South Slav lands.

There were some Serbs in the Slav section of the International which Bakunin formed in Zürich late in 1871 , and indeed their presence made the section widely known as the "Slavenski savez" (Slav League). ${ }^{6}$ But the Serbs who went over to Bakunin were not,

\footnotetext{
1 Der Volksstaat, no. I 4, I 7 February I 872.

2 Ibid., no. 32, 20 April I 872. There were at the time tailors' strikes in Leipzig and Fürth; in the latter city the apprentices were seeking a 25 per cent pay increase and a reduction of the work week to 66 (sic) hours; see ibid., no. 26, 30 March 1872.

3 Radenik, no. 44, 23 April 1872.

4 L'Égalité, no. 2, 28 January 1872 . The subscription for "Serbie B. M.M.S." is apparently "Belgrade, M. Marković Svetozar".

${ }^{5}$ J. M. Meijer, Knowledge and Revolution, Assen, I955, pp. 89-90, 94-95; E. N. Kusheva, "Iz russko-serbskikh revoliutsionnykh sviazei", loc. cit., pp. 35 2-353.

${ }^{6}$ This section was formed in October of 1871 and was admitted to the International on 30 January 1872 . It should not, of course, be confused with the regular Zürich section
} 
with the exception of Manojlo Hrvaćanin (who left the anarchists a few years later) of a very high order. When Nikolai Utin suffered a severe beating in Zürich in July of 1872 he lodged a complaint with the police against some Serbs residing in the city; ${ }^{1}$ the Serbs tended to interpret Bakunin's call for violent uprisings rather liberally. All the Serbian anarchists soon drifted into obscurity or ignominy. ${ }^{2}$

In general the stable, serious individuals among the Serbian radicals stayed with the marxist (after 1872 , loyalist) groups in the International. Hermann Greulich told Becker in I873 of "some Serbians" who were members of the loyalist section in Zürich, and Becker himself spoke of an unidentified Serbian delegate to the loyalist congress in Geneva in $1873 .^{3}$ The point to be made here is that the Serbs were certainly not following Bakunin or any other individual merely because he was a Russian and a brother Slav; on the contrary, the vast majority of the Serbian radicals followed a German, and not a Russian lead.

As significant as the failure of the Bakuninists to capture the Serbian radical-socialist movement was the development of close relations between the radical-socialists and the Karadjordjevists. Locked in a struggle with the Obrenovic family since the first Serbian uprising against the Turks (1804-1812), the Karadjordjevićes came in the I $870^{\circ}$ 's into a loose alliance with the extreme left-wing elements in Serbia. Svetozar Marković and his family had long been in the Karadjordjević camp, and Vlada Ljotić, whom we have already met in Becker's company in Geneva, was at once a leading radical-socialist and a close friend and ally of the Karadjordjević clan. All this has been known to specialists in the field for some time, but there are previously unknown documents which now provide proof of earlier and more extensive cooperation between radical-socialists and $\mathrm{Ka}$ radjordjevists than has been suspected.

Vlada Ljotić registered with the Geneva police on in March 1872. He was traveling on a Serbian passport issued in Paris in July of i 870 to Djordje Karadjordjević. Also on the passport was a third individual,

founded in 1867 by Hermann Greulich and Karl Bürkly. Greulich wrote to the Genera Council on 18 December 187 I and announced the reorganization of his section, noting that "in our Section are also members of the Russian and Polish nationalities (no Bakuninists)". See IISG, Jung Papers, no. 973.

1 IISG, Smimov Papers, Afz. Stk. IV, Sminnov to A. S. Buturlin, i I August 1872.

2 Jovan Skerlić, Svetozar Marković (2nd ed., Belgrade, 1922), p. $87 \mathrm{n}$. traces the fate of some of them.

${ }^{3}$ J. M. Meijer, Knowledge and Revolution, p. 97; Der Volksstaat, no. 95, 8 October 1873 :

"Es war derselbe von 3 I Delegirten gebildet... wovon 18 deutscher... 9 französischer

(Franzosen und Schweizer), 2 italienischer, I holländischer und serbischer Sprache." 
Arsen Karadjordjević. ${ }^{1}$ The two latter men were cousins, both of them grandsons of Black George Petrovic (Karadjordje), the leader of the first uprising. Neither was a pretender to the throne; Arsen's elder brother Petar held that position and was eventually to become king of Serbia (1903) and later of the Kingdom of the Serbs, Croats and Slovenes (1918).

Shortly before Christmas of 1872 the two Karadjordjević cousins and Ljotić joined the pretender, Petar, in Zürich. From that city Ljotić wrote the following letter to Becker:

Mein lieber Becker,

Zürich, I6.I 2.72

Warscheinlich hat es dich gewundert, dass ich wie versprochen Montag abends im Temple Unique nicht erschien. Weniger wunderlich wird es dir sein, wen ich Dir sage, dass ich denselben Tag um 8 Uhr abends schon im Zürich gewesen, wo ich eiligst berufen war. Dass es so geschehen ist mir am meisten leid, denn noch vieles könnte ich mit dir sprechen und von Dir erfahren. Ueber allem ist es mir leid, dass ich Dich nicht beim weggehen sehen konnte, es war überhaupt unmöglich. Noch tröste ich mich damit, dass $\mathrm{Du}$ mir dafür nicht zürnen wirst.

Heute reise ich nach Wien, wo ich mich warscheinlich einige Tage aufhalten werde. Ich werde nicht versaumen mich mit allen dort zu sehen. Wen ich etwas interesantes warnehme, versteht sich, so was, was Dich interesiren könnte, so werde ich Dir schreiben.

Hier im Zürich, stehet alles beim altem. Übrigens weist $\mathrm{Du}$ alles was hier geschiet noch viel besser als ich.

Von Wien aus, werde ich nach Neusatz (Ungarn); und dan nach Serbien. Treten nicht auserordentliche verhältnisse ein, so werden wir im Belgrad ein neues Blatt gründen, der mehr unseren principien ensprechen wird. So etwas, wolten wir auch im Ungarn probiren, aber es gieng nicht - und allenfals darum nicht, weil wir zu vereinzelt waren. Im Allgemeinen, im Ungarn, wird uns nur dan, die schriftliche propaganda ermöglicht, wen dieselbe von Ungarn selbst mehr verbreitet wird, wen sie mehr im Volksmassen eindringt, und sich nich nur auf Arbeiter Pest's begränzt. Den in einem Lande, welches so einen calembours von Völkerschaften darstellt, wird nur dan auf einen Erfolg gerechnet werden können, wen die Propaganda gemeinschaftlich wird. Den nur so kann der Hass, der zwischen verschidenen nationalitäten be-

1 AEG, Étrangers, Dh 24, p. 53, nos. $58031-58033$. 
stehet gelindert und mit der Zeit auch ganz abgeschaffen werden. - So beehtrachtend die Sachlage - haben wir probirt, mit SocialDemokraten in Pest näher zu treten; aber der Erfolg ist bis jetzt noch beinahe gar keiner. Und da könntest Du uns viel nützen. Und nicht nur Du, sonder alle, die mit jenen in Pest in Verbindung stehen. -

Es wäre mir sehr lieb, wenn du mir Deine Gedanken über diesen Gegenstand mittheiltest. Ein anderes mal werde ich mich bemühen, mehr verständig zu werden, und für dies mal, mögest du mir verzeihen, wenn ich dir mit diesen Zeilen eine Pflage vorbereitet. Siehe, ich muss mich noch sehr pflagen, wenn ich mich verstängig machen will.

Meine Adresse im Wien ist: Nikola Neschitsch Niebellungen Gasse no. I I (für Ljotitch). und für Neusatz: Zlatna Greda no. I93I.

Und für jetzt noch, sei mir gesund und froh

\section{Dein W. M. Ljotitch}

Um sicherer deine Briefe zu erhalten, adresire mir auch so: Mlles Ninkowitch, Oberstrass no. I9I, Zurich, oder: Mr. Petar Gyorgyewitch Oberstrass. Neues-Schulhaus. ${ }^{1}$

We note in this letter a warm and friendly relationship between Ljotić and Becker, and we further note that Ljotić had evidently become a regular visitor at the Wednesday evening meetings of the Geneva Central section of the International. His presence in the Temple Unique would have occasioned no surprise; Becker, A. A. Serno-Solov'evich, Nikolai Utin and other foreigners had played prominent rôles in the section for years, and Geneva Central was one of the most "international" units in the parent organization. As the only Serb known to have attended these meetings, Ljotic would have been in a position to keep the radical-socialists in Serbia fully and promptly informed of developments in the International.

Ljotic's reference to the plans of the Serbian socialists to found a new journal is the first indication that such a project was in the making. It was realized only in November of 1873 when the Marković group began publication in Kragujevac of the newspaper Javnost (Public Opinion).

Serbian socialist activity in the Vojvodina, as we note in Ljotic's letter to Becker, was obviously under severe restrictions. Svetozar Marković was expelled from Novi Sad in March of 1873 , and colla- 
boration with the social democrats in Budapest was hampered not only by the nationality problem Ljotic mentions but also by the reaction which followed the treason trial of the leading Hungarian social democrats in the spring of $1872 .^{1}$

Finally, the names mentioned in Ljotic's letter are significant. I have been unable to identify Nikola Nešić, but Anka and Milica Ninković were the first female socialists in Serbia and were to play an important role in the movement. ${ }^{2}$ Petar Karadjordjević was of course the embodiment of opposition to the ruling Obrenović dynasty. The mariage de convenance between the radical-socialists and the Karadjordjevists continued for another decade, ${ }^{3}$ and it was the Radical party, one of the offshoots of the socialist movement of the I870's, which brought the Karadjordjevices to power in 1903.

Serbian ties with the Central European social democrats continued to develop after 1872 . When he began to publish Javnost (Public Opinion), one of Svetozar Marković's first concerns was to enter a subscription to Der Volksstaat for the staff of the new journal. 4 Nikola Markovic, who was apparently a key figure in the first Serbo-Croatian translation of the Communist Manifesto, ${ }^{5}$ began subscribing to the Zürich Die Tagwacbt ${ }^{6}$ and maintained his contacts with Der Volksstaat; he was shortly to become a regular correspondent for the latter newspaper.

The number of Der Volksstaat's subscribers in the South Slav lands grew to a total of ten - perhaps not a very impressive number but one sufficiently large to cause the journal to begin listing (June 1873 ) the cost of a subscription in Serbia. In the third quarter of 1873 the Leipzig social democratic newspaper was received at Zagreb and Dubica in Croatia, Stara Gradiška in Slavonia, Pančevo in the Vojvodina, Zemun in Austrian Military Frontier district and Belgrade (three subscribers), Smederevo and Kragujevac in Serbia.?

Late in February of 1874 Der Volksstaat informed Nikola Marković that it was considering his article for publication. ${ }^{8}$ The article in

${ }^{1}$ On that trial see Der Volksstaat, nos. $36,37,4$ and 8 May 1872 . On the socialist movement in the Vojvodina see Laza Nančic, Izabrani politički spisi, Novi Sad, 1961.

${ }^{2}$ See D. Ilić, Prve žene socijalisti u Srbiji, Belgrade, 1956, pp. 17-36, and Meijer, Knowledge and Revolution, pp. 89-90, 96, 185 .

3 See Eduard Bernstein, Aus den Jahren meines Exils, Berlin, 1918, pp. 119-120.

4 Der Volksstaat, no. 1 ro, 12 November 1873.

5 Bert Andréas, Le Manifeste Communiste de Marx et Engels: Histoire et Bibliographie, I 848-1918, Milan, 1963, no. 56.

- Die Tagwacht, nos 3, 19, 18 January and 1o May 1873.

7 Der Volksstaat, nos. 52, 93, 28 June and 3 October 1873 . In this same peziod only one copy was received in Amsterdam.

Ibid., no. 24, 27 February 1874 . 
question was not identified, but it surely had to do with the case of Svetozar Marković and his colleague Dimitrije Stojković, collaborators on Javnost, who had just been convicted of violating the Serbian press law and sentenced to prison. ${ }^{1}$

The Marković-Stojković trial had become a cause célèbre in Serbia, and it is a little surprising that Der Volksstaat dit not carry an account of the trial until early in April. In a brief and rather pedestrian article, Laza Nančic came to the conclusion that the Serbian trial had strengthened the local socialist movement in the same way that the BebelLiebknecht high treason trial had aided the cause of the German socialists. ${ }^{2}$

A much lengthier version of the Serbian events, which also included a history of the radical-socialist movement, was published in Der Volksstaat in June and July of $1874 .^{3}$ The writer, who was surely Nikola Marković, took issue with Nančićs version, finding it both erroneous and incomplete, and undertook to set the record straight.

In this year of Svetozar Marković's trial and imprisonment, socialist activity in the South Slav lands increased in scope and intensity. In Croatia the Zagreb workers established their own journal, Der Arbeiterfreund - Radnicki prijatelj. This first socialist newspaper in the Croat lands was edited first by Dragutin Kale and after December of I 874 by Franjo Potisk. Harried by the Hungarian authorities, the journal reorganized in August of 1875 and changed its name to Der Neue Arbeiterfreund, but at the end of the same year it quietly expired. Had it not met such an untimely death, the Zagreb socialist journal, which had excellent contacts in Germany and Serbia and throughout the Habsburg Empire, might have played an important rôle in unifying the socialist movement in the South Slav lands.

In the Serbian areas, at least nineteen socialist newspapers, weekly journals and literary reviews were founded in the period I $871-1875 .{ }^{4}$ Svetozar Markovic was associated with only four of these (Radenik, Javnost, Glas Javnosti (The Voice of Public Opinion), Oslobodjenje (Liberation), further indicating that his domination of the Serbian

1 On the trial see my Marković, pp. 222ff.

2 Der Volksstaat, no. 4I, 10 April 1874 .

${ }^{3}$ Ibid., nos. 66, 84, 10 June and 22 July 1874 . In the latter issue Liebknecht inserted a note to the effect that Bismarck, as the author of the new "press-muzzling" law in Germany, would feel at home in the company of the Serbian lawmakers who decreed cudgeling for those convicted of press crimes.

4 Vuletić, Svetozar Marković, lists thirteen of the publications (pp. 201-202). He does not include the Marković journals, nor does he mention Graničar (The Frontierist - published in Zemun in 1874 by Jovan Pavlović and Nikola Marković) or Rad (Labor), which Pera Todorović began to publish in Belgrade in 1874 . 
movement has been exaggerated. Many of the socialist publications appeared only briefly, and in several cases not a single copy has survived. The number of these socialist sheets clearly demonstrates, however, the growth and the widespread nature of the movement in Serbia; eleven were founded in the months after Markovic went to prison.

As his friends had all too accurately predicted, Svetozar Marković died three months after his release from prison. On 17 March 1875 Der Volksstaat carried an obituary in a black-bordered place of honor on the front page. ${ }^{1}$ Laza Nančic was apparently the author of the sad lines, "A severe blow has stricken Serbian social democracy - the noble, meritorious Serbian socialist, Svetozar Markovic, is no more."

Markovic's death at age twenty-eight, after a cruel prison term, gave the Serbian socialist movement a martyr and thus a new dignity. The Serbs could now say to the Germans and others, we too have suffered for our convictions. The Serbs rightly saw themselves in a position of enhanced importance in the international movement. Liebknecht began to publish in Der Volksstaat the articles and news items sent to him by Nikola Marković, Jaša Tomić, Laza Nančić and others; the news from the Balkans provided one more indication that, though the International was dead, the European socialist movement was alive and growing. The Leipzig social democratic journal now regularly carried an "Aus Serbien" column, the tribulations of the Serbian parliamentary socialists were reported in the journal, and Nikola Marković's silence of a few months caused Liebknecht to express concern. ${ }^{2}$

Spurred in part by socialist propaganda and activity among the peasants, an armed uprising erupted in Hercegovina in the summer of I 875 against the Turkish landlords. Der Volksstaat devoted considerable space to the events in Hercegovina, and was by the end of August receiving and publishing regular reports from an unidentified Serb, who saw the uprising as a prelude to a general Balkan revolution against the Turks. The editors of the German socialist newspaper disputed their Serbian correspondent's interpretation, maintaining from the beginning that the "revolution" was in reality a Russian plot to substitute the domination of "Väterchen" Alexander II for that of the Sultan over the Balkan Christians. ${ }^{3}$ The German social

1 Der Volksstaat, no. 3I. Nančić, then studying in Vienna, accompanied Marković's body from Trieste to the Rumanian-Serbian frontier; see his Izabrani politički spisi, V/1, p. 36.

2 Der Volksstaat, April-May-June-July I 875.

3 Ibid., no. 97, 25 August 1875. The best book on the uprising remains Vasa Cubrilovic's Bosanski ustanak 1875 -1878, Belgrade, 1930 . 
democrats continued to purvey this argument throughout the remainder of the year. At one point they exhumed the "testament" of Peter the Great, which most educated people knew had been fabricated at Napoleon's order, in the attempt to prove the imperialist designs of Russia. ${ }^{1}$

The socialists in Serbia were bitterly disappointed by the refusal of the Germans to support their position on the significance of the events in the Balkans. Laza Nančić and Jaša Tomić wrote a detailed explanation of the insurgents' goals and sent it to Liebknecht, who refused to publish it. ${ }^{2}$ The German attitude was expressed in an item published in Der Volksstaat in February of 1876 :

" $A$ communist uprising in Serbia is imminent, according to Viennese newspapers. This will surely not be, and even if it were true it would signal nothing more than a hopeless struggle. The socialist-communist society cannot, in the first place, be established in a small, industrially and intellectually underdeveloped statelet." 3

This patronizing attitude, however sound it may have been, outraged the Serbs. The item quoted here was published on the eve of the first large-scale socialist demonstration in Serbian history. On this "Day of the Red Flag" the followers of Svetozar Marković led some hundreds of teachers, students and workers in a mass demonstration in Kragujevac at which scores of red flags were displayed and many inflammatory speeches delivered. Many of the leaders of the demonstration were arrested and imprisoned. 4

Obsessed by their Russophobia, and confident of the accuracy of their analysis of the Balkan situation, the German socialists remained unimpressed by this Serbian show of strength. Liebknecht did resume his policy of publishing the Serbian side of the question, but he could not resist adding a note to one article written by Nančić or Kosta Lera: "That there are intrinsic grounds for the uprising we never doubted; that Russia stands behind them we doubt just as little..."5

Relations between Serbian and German socialists continued to deteriorate. In June of 1876 a Serbian correspondent complained bitterly of the insults heaped on the Balkan insurgents by Der Volksstaat. Liebknecht and his staff caustically replied that they should

1 Boris Mouravieff, Le Testament de Pierre le Grand: Légende et réalité, Neuchâtel, 1949; the "testament" is reproduced on pp. 73-77.

2 Nančić, Izabrani politički spisi, V/r, p. Io.

3 Der Volksstaat, no. 21, 20 February 1876.

4 Glasnik Srpske Akademije Nauka, III, no. 2, 1951, Pp. 32 1-322; Der Volksstaat, nos. 32 and 43, 17 March and 12 April 1876.

5 Der Volksstaat, no. 43, 12 April 1876. 
have limited their use of the term "sheep thieves" to the Montenegrins, and should have identified the Hercegovinians not as "cutthroats" but rather "headcutters" in view of their predilection for decapitating fallen enemies. The Serbs were advised not to expect from Leipzig the same sympathy and support that would be accorded an uprising of the Parisian proletariat. Though the cause of the Hercegovinians might have some merit, said Liebknecht, the peasants of that area "are not developed enough to defend the principles of modern revolution."

After months of acrimonious debate the situation began to improve. Liebknecht stopped attaching insulting footnotes to the articles the Serbs sent in to Der Volksstaat, and the German socialists began to take a relatively more objective stand on the Balkan situation. St. Petersburg's hesitation tended, at least through i 876 , to discredit the "Russian conspiracy" theory, and the Germans seemed to move a little closer to the Serbian view of the uprising, which held that it was a social revolution against feudal landlords and a national revolution against Turkish rule. ${ }^{2}$

The number of South Slav subscribers to Der Volksstaat grew to sixteen in 1876 , again not a large number, but much would be made of it if today a similar number of subscriptions to Jen min jib pao were reported to be circulating in, say, Bolivia. Be that as it may, Der Volksstaat was received in the Balkans, and its conciliatory line improved the prospects for recapturing the mood of socialist camaraderie that had prevailed for a few months after Svetozar Markovićs death.

In September of $1876 \mathrm{Der}$ Volksstaat began to serialize one of Svetozar Marković's articles on materialism. ${ }^{3}$ This lengthy article, together with one on the situation in Hercegovina, was translated into German and sent to the newspaper by Laza Nancić. Strangely enough, Nančić, who had sent the articles in March, did not at first identify Marković as the author, and asked for a payment of fifty florins for himself. This unusual behavior becomes even more puzzling when we note that Nančić also sent one of Kautsky's early articles to Der Volksstaat, again failing to identify the author. He did not, however, ask for payment for the Kautsky article; it is possible that the then unknown Kautsky may have asked Nančić (whom he met in Vienna) to send his article to the Leipzig newspaper. ${ }^{4}$

1 Ibid., no. 75,30 June 1876 .

2 Ibid., nos. 47, 48, 23 and 25 April $187^{6}$.

3 "Die materialistische Richtung in der Wissenschaft", ibid., nos. 109-II4, 17, 20, 22, 24, 27 and 29 September 1876.

4 IISG, Motteler Papers, no. 2809, Nančić to Der Volksstaat, 8 April 1876 . Kautsky's article in question was: "Der Socialismus und der Kampf um das Dasein", in: Der Volksstaat, nos. 49 and 50, 28 and 30 April 1876 . 
The six issues which carried Nančić's translation of Marković's work (under the author's name, as it happened) were the last of Der Volksstaat's independent existence. After the unification of the two German social democratic factions in 1875 , the Gotha congress of 1876 voted to amalgamate the organs of both factions under the new title Vorwärts. The new journal continued the attempt to reestablish cordial relations with the South Slavs. There were flashes of hostility and sarcasm now and then - the Germans blamed the worsening of the beer on cheap Croatian hops ${ }^{1}-$ but on both sides there was an effort to heal the breach brought on by the Balkan crisis.

The reconciliation was not to last. The Serbs continued to castigate the Germans for failing to support them in the struggle against the Turks, and to insist that their program calling for the overthrow of Turkish feudalism was unassailable on any grounds. The Germans answered that the Serbs had missed the point. The Russian declaration of war in the spring of 1877 seemed to prove that the German position was correct. The Serbs, Vorwärts now said, were going to have to pay for their illusions about the tsar. ${ }^{2}$

Both sides were quite right in their positions. The Serbs were on safe grounds in calling for a popular uprising against the Turks, and in hoping to use the national movement to effect sweeping social reforms. ${ }^{3}$ The problem was that they let the war issue get out of hand, and lost the initiative to Prince Milan and his advisers. Fearing socialism more than war, Milan, originally hostile to Serbian involvement, pre-empted the cry for war and called for Russian support; a fumbling government in St. Petersburg was galvanized into action. The Serbian socialists were thrown into disarray.

The Treaty of San Stefano confirmed the predictions of the German socialists. Immediately after the treaty was signed Vorwärts took the Serbian party severely to task. Noting that the Serbs had gotten off to a good start by creating a party in the German image (!), the writer (C. Stichlet) was perplexed as to the reasons why the Serbs deviated from the policies spelled out for them by their German tutors. Stichler pointed out that the Serbs had repeatedly been warned that the uprising in Hercegovina would be mercilessly sacrificed to outside interests.

The Serbian socialists, the Vorwärts writer observed, had failed to appreciate their own strength. The very founding of their party, coupled with the disintegration of the old "pasha economy," had

1 Vorwärts, no. 26, 29 November 1876.

2 Ibid., no. 14, 2 February 1877.

${ }^{3}$ Slobodan Jovanović, "Serbia in the Early 'Seventies", in: The Slavonic Review, IV, 1925-26, P. 393. 
guaranteed eventual victory. The Serbian government had correctly seen in 1876 that only a war could save the regime; the war against the Turks thus became, far from a war of national liberation, a war to preserve the existing political and social order in Serbia. By supporting the war despite the anguished warnings from Germany, the Serbian socialists had sealed their own doom.

In conclusion Vorwärts urged the Serbs to accept the fundamental truth that Russian despotism was an infinitely more dangerous enemy than the British "Krämer-Politik". This gratuitous reference made more sense by far in Germany than in the Balkans. The German social democrats were confident, Stichler wrote, that the Serbian comrades had lost neither their courage nor their taste for the social struggle; victory was assured - if only the Serbs would follow the German example. ${ }^{1}$

But victory was not to be attained by imitating the German socialdemocratic party, which itself was to find victory singularly elusive. The Germans failed to appreciate the awkward position in which the Serbian socialists and their less numerous and influential counterparts in Montenegro and Bulgaria found themselves on the question of the war. The South Slavs had indeed failed to see that, far from creating an issue on which they could overthrow the Obrenovic regime, they had with their bellicose policy given that regime the perfect means of neutralizing its opponents; it is difficult for a "war party" in opposition to outdo a similar party in power. On this count the Germans were certainly right, but there was more to the problem.

The German socialists had in effect told the South Slavs that they were not miserable enough for socialism, or rather that theirs was the wrong kind of misery. This was the cruel logic of marxist determinism. The South Slavs had to go through capitalism, become "proletarianized", before marxist socialism would make any sense to them. It is not surprising that in Serbia, at least, no marxist party appeared until I903. It is academic, perhaps and certainly it is beyond the scope of this paper, to try to determine whether the Serbs failed marxism, or vice versa.

Some of the South Slavs, motivated at least in part by their disillusion with the German rapprochement, sought to restore the old ties with the Russians. Those ties had been created by Svetozar Marković and Liuben Karavelov in the late I860's, and had involved both groups in Russia (notably the secret Smorgon Academy) and émigré organizations such as the Russian section of the International. The latter had ended its active work in 1872 ; its place as the most

1 Vorwärts, nos. 32, 33, 17 and 20 March 1878. 
influential non-anarchist Russian émigré organization was taken by the group around Peter Lavrov and his Vperëd! (Forward!). Lavrov's people were in contact with the Balkan Slavs at least as early as 1872 ; by January of 1873 Valerian Smirnov boasted that Vperëd!, of which he was the secretary, had established a distribution system in every Slav land except Poland. ${ }^{1}$ Smirnov received at least one Montenegrin journal for a time $;^{2}$ it would in any case seem unlikely that he received only this one publication from the Balkans, doubly unlikely in view of the fact that Vperëd! was, by 1875 , listing three obscure Serbian newspapers among the socialist journals it recommended to its readers.

Late in 1875 Lavrov's journal joined the German social democratic press in criticizing the Serbian socialists' interpretation of the events in Hercegovina and Bosnia. Whatever else those events might signify, the London Russians held, they did not constitute a social revolution. ${ }^{3}$ But two years later Valerian Smirnov and to a lesser extent Lavrov himself had parted company with the Germans on this issue. Smirnov wrote to Rozaliia Idel'son in February of 1878 that he feared Liebknecht would compromise himself with his latest brochure on the Eastern Question; all the German socialists - Marx, Engels, Lassalle and the others - were, he wrote, nationalists when it came to political questions. ${ }^{4}$

Fragmentary evidence in the valuable Smirnov Archive, located in the Amsterdam International Institute for Social History, indicates that Vperëd! contacts with the Serbs increased toward the end of the decade. In July of 1878 Svetislav Minić, editor of the Vršac journal Bratstvo (Brotherhood), sent a letter to the London Russians through Nastal Ivanović suggesting an exchange of books, newspapers and information. Konstantin Stanišić, co-editor of the liberal Belgrade newspaper Istok (The East), wrote asking that Vperëd! be sent to him and offering to supply correspondence from Serbia in return. An unidentified Persida Nikolajević wrote from Arad asking for information on revolutionary developments in Russia. ${ }^{5}$

Even if we assume that there were in addition to these letters others which have not been preserved, we still cannot prove, on this evidence alone, anything further about the socialist movement among the South Slavs in the period after 1878 . The reason for this is simple:

1 IISG, Smimov Papers, Afz. Stk. IV, Smimov to Buturlin, January 1873.

2 Ibid., IA(3), Lavrov to Idel'son, 14 November 1873.

3 Verëd! (London), no. 21, is November I875, pp. 671-672.

4 Smimov Papers, Afz. Stk. III, p. 86, letter no. 91, Smimov to Idel'son, 4 February [1878].

5 Ibid., Minić to Vperëd!, 3 I July I878 (Minić mentions his collaboration with Stevan Milićević, one of Svetozar Markovićs colleagues); Stanišić to Vperëd!, undated; Persida Nikolajević to Vperëd!, I9 April 1878. 
until the founding of social-democratic parties early in this century, there was no Serbian or Bulgarian or other South Slav left, merely scattered leftists. The socialist movement disintegrated in the frustration and disappointment which followed the Congress of Berlin. Repression and reaction in the Germany of Bismarck, the Russia of Alexander III, left socialist forces in those countries little opportunity to render any kind of assistance, even moral support, to the scattered remnants of what had been, in the $1870^{\circ}$ 's, a promising movement in the Balkans. ${ }^{1}$

In conclusion, let us consider the significance of the arguments presented here. It is in the first place clear that the birth of the socialist movement in Serbia (the first such movement in the Balkans) was marked by considerably more extensive contact with Central European social democracy than we have previously thought. But what precisely did this "contact", sketched here in barest outline, mean?

It meant in the first place that the Serbian intelligentsia (I use the word in the Russian sense) of the I 870's was certainly not, as the traditional interpretation has led us to believe, mesmerized by the Russian "revolutionary democrats". The Serbs were on the contrary a surprisingly (given conditions in Serbia one is tempted to say amazingly) sophisticated group. They were well acquainted with the avant garde social teachings of the West, teachings which they disseminated throughout Serbia in more than a score of newspapers and journals in the period $1871-1878$. The Serbian Left of those years belonged at least as much in the camp of social democracy as in that of Russian populism, and this despite the fact that Russian rather than Central or Western European conditions were more nearly approximated in Serbia (agrarian society, little capitalist development, small working class, etc.). Why then were the Serbs attracted to social democracy? In answering this question it should of course be made clear that we are dealing with a tiny, if disproportionately influential, group of Serbs. The fact that some of the Serbian newspapers (Oslobodjenje and Radenik, for example) had over a thousand subscribers does not necessarily mean that there were that many socialists in the country, and even if there were the fact of their relative numerical insignificance is unchanged.

The Serbian Left was drawn to social democracy in the first place because it was international. It is sometimes difficult to grasp the

1 IISG, Smirnov Papers, has a letter from the Bulgarian Ivan Dobrev to Vperëd! of 30 April 188,5 requesting collaboration in the exchange of newspapers and books. A Bulgarian socialist, Georgi Manoilov, got in touch with Bernstein in 1889 and made a plea for help in his effort to propagate socialism (IISG, Julius Motteler Papers, 798/2). 
fact that Europe in the 1870 's knew little more about the Serbs than about the Eskimos; this was doubly and triply true of the European working class. Aware that they had to establish their identity, several of the Serbian leftists sought to communicate with the International, the program of which offered them both recognition and certain guides to progress.

Those theoretical guides to progress, ambiguous though they often were, were the second reason for the attraction which social democracy held for the Serbs. This is not the place to discuss the program of the International; suffice it to note that the Serbs interpreted that program to include collectivization of the land, public ownership of the means of production, complete equality of all citizens, and a reduction in the size, influence and cost of the apparatus of the state. These were the general principles upon which the Serbian socialists of the i 870 's grounded their specific programs. Those programs, poorly worked out and frequently contradictory though they were, nevertheless made the Serbs part of the social democratic movement.

Serbian socialism combined elements of social democracy and Russian populism, remaining in the end closer to the former. The Serbs had in this period rather more extensive knowledge of and contact with social democracy than had the Russians in Russia (as distinguished from the émigré groups), and it is not to be wondered at that social democracy made more headway in Serbia than in Russia in the $1870^{\prime}$ s. In comparison with Russia, Serbia, with all its shortcomings, was a relatively liberal society, and at least for a time the government was unable to halt the spread of socialist convictions among some segments of the population.

It remains finally to consider the reasons for the failure of the socialist movement in Serbia. After a promising beginning there was a hiatus of nearly a generation in which there was no socialist movement of any consequence in the country; how do we account for this?

We note immediately that Svetozar Marković died too young. His martyrdom at age twenty-eight helped the movement briefly, but memories dimmed, and all but a handful forgot. What the Serbian socialists needed after 1875 was strong leadership; this they did not have, despite the fact that some individuals (Pera Todorović, Vasa Pelagic and others) were capable and aggressive crusaders for the cause. Secondly, the Serbian socialists were in the peak years of their power $(1875-76)$ to a great extent victims of their own success. This paradoxical situation arose when the socialists presented a united front on the war issue. Whatever the merits of the war against the Turks, it would seem that a strong, or at least a vocal, anti-war 
faction within the socialist movement might have staved off the disaster which befell it when the government pre-empted its war program. Certainly it would not have been easy to convince the Serbs to fight their own government rather than the Turks; this was after all a nationalist, not a socialist, era. But other, more experienced parties had faced the same situation (e.g., the Franco-Prussian War) and had emerged stronger; it was a sign of the Serbian movement's fatal weakness that its strength was too concentrated, its ranks too united.

These, then, were the Serbian social democrats of the I 870 's. They were a small band, a few critically thinking individuals whose minds and consciences had not been dulled in cozy bureaucratic sinecures, and they adopted the program being pursued by the most radical leaders of the Central and Western European working class. Their first steps were highly tentative, but they were taken relatively early and they were largely inspired by the teachings of the marxists and the experience of the First International. ${ }^{1}$

1 Two important articles which appeared too late for inclusion in this study are Vitomir Vuletić, "Svetozar Marković i Prva internacionala", and Milena Gecić, "Prvi socijalistički list u Srbiji ‘Radenik' i Prva internacionala”, in: Prilozi za istoriju socijalizma, 1966, no. 2, pp. 1 59-1 79, 383-392. While they do not present any important new material, these studies do strengthen my contention concerning the extent and significance of the Serbian socialists' contacts with the First International. 